Article-Biological and Applied Sciences

\title{
Anti-Helicobacter pylori and Anti-inflammatory Properties of Eugenia uniflora L.
}

\author{
Jessica Raquel Borges Monteiro' \\ https://orcid.org/0000-0001-9279-9187 \\ Juliana Santa Ardisson ${ }^{1}$ \\ https://orcid.org/0000-0002-0754-0865
}

Brena Ramos Athaydes ${ }^{1}$

htpps://orcid.org/0000-0002-8954-771X

Rita de Cássia Ribeiro Gonçalves ${ }^{1}$

https://orcid.org/ 0000-0001-9352-2454

\section{Ricardo Pereira Rodrigues ${ }^{1}$}

https://orcid.org/ 0000-0002-2924-0468

Ricardo Machado Kuster ${ }^{2}$

https://orcid.org/ 0000-0002-8961-5348

\section{Rodrigo Rezende Kitagawa ${ }^{1^{*}}$}

https://orcid.org/0000-0002-2208-6699

\begin{abstract}
${ }^{1}$ Federal University of Espirito Santo, Health Science Center, Graduate Program in Pharmaceutical Sciences, Vitoria, ES, Brazil; ${ }^{2}$ Federal University of Espirito Santo, Department of Chemistry, Laboratory of Chromatography, Vitoria, ES, Brazil.
\end{abstract}

Received: 2018.06.08; Accepted: 2019.06.22.

*Correspondence: rodrigo.kitagawa@ufes.br; Tel.: +55-27-3335-7307 (R.R.K.)

\section{HIGHLIGHTS}

- E. uniflora MeOH extract has anti-Helicobacter pylori activity;

- E. uniflora showed antioxidant and immunomodulatory effects;

- Some tannins and flavonoids identified are reported to biological activity;

- E. uniflora is source of bioactive compounds for $H$. pylori infection treatment.

Abstract: Helicobacter pylori is a bacterium that reaches half of the world population and it's recognized as the main cause of chronic gastritis and peptic ulcer. In this study, we evaluated the anti- $\mathrm{H}$. pylori, antioxidant and immunomodulatory activities of the methanolic $(\mathrm{MeOH})$ extract of Eugenia uniflora leaves and chemical profile. Anti- $\mathrm{H}$. pylori activity was evaluated by spectrophotometric broth microdilution technique by determining the 
minimum inhibitory concentration (MIC) and minimum bactericidal concentration (MBC), in addition to the evaluation of the effect on the urease enzyme. The antioxidant activity was evaluated by capturing $\mathrm{O}_{2}{ }^{*}, \mathrm{HOCl}$ e $\mathrm{NO}^{*}$ radicals. The immunomodulatory effect was evaluated on the cytokines TNF- $\alpha$, IL- 6 and on nitric oxide through inhibition in LPS-stimulated macrophages. The chemical profile was performed by total phenolic, tannin and flavonoid contents and mass spectrometry analysis by ESI-FT-ICR MS. In the anti- $H$. pylori assay the extract showed MIC of $128 \mu \mathrm{g} / \mathrm{mL}$, however it did not obtain MBC. The extract also showed ability to inhibit the urease enzyme about $20 \%$. The antioxidant activity of the $\mathrm{MeOH}$ extract showed EC $\mathrm{E}_{50}$ values of $29.77 \mu \mathrm{g} / \mathrm{mL}, 15.71 \mu \mathrm{g} / \mathrm{mL}$ and 442.10 $\mu \mathrm{g} / \mathrm{mL}$ to $\mathrm{O}_{2}{ }^{*}, \mathrm{HOCl}$ and $\mathrm{NO}^{*}$, respectively. The extract also showed influence on the release of TNF- $\alpha$, IL-6 and NO in LPS-stimulated macrophages, ranging from $39 \%$ to $97 \%$ inhibition. Flavonoids, phenylpropanoids, tannins, triterpenoids and carbohydrates were the major classes of compounds present in the $\mathrm{MeOH}$ extract as identified by $(-)$-ESI-FT-ICR MS. The results indicate important anti- $H$. pylori, antioxidant and immunomodulatory activities from Eugenia uniflora highlighting its importance in the prevention and treatment of diseases caused by $H$. pylori infection.

Keywords: Eugenia uniflora; Helicobacter pylori; antioxidant; immunomodulation.

\section{GRAPHICAL ABSTRACT}

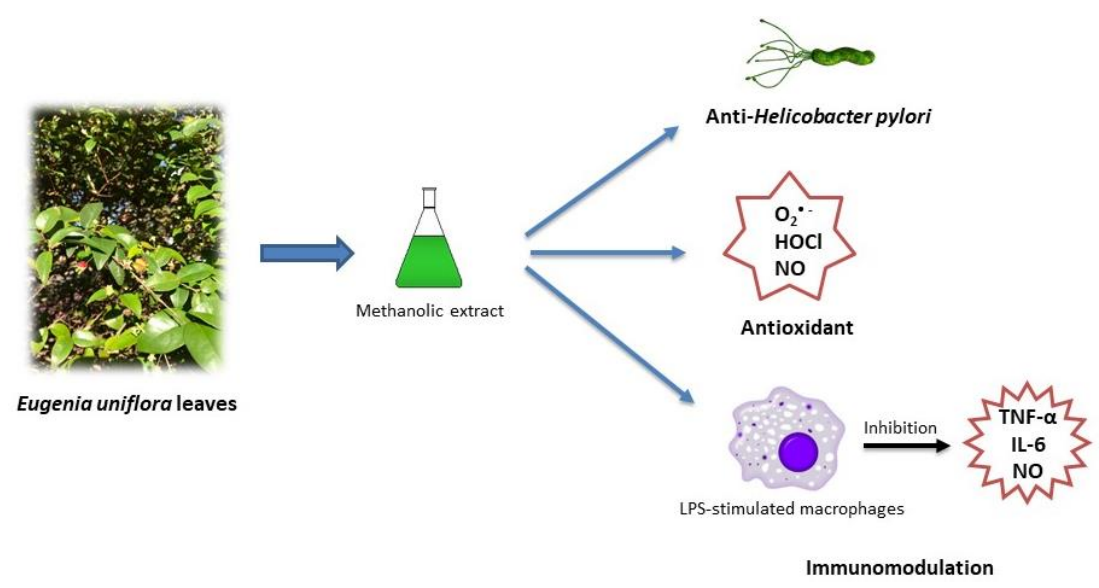

\section{INTRODUCTION}

Gastritis and gastric ulcer are disorders characterized by the disruption of normal gastric mucosal integrity and are associated with complications such as cancer. The incidence of these diseases varies according to the age, gender, geographic location and represents a global health problem due to its high morbidity and mortality. The possible causes are credited to the excessive use of anti-inflammatory drugs, food poisoning, ethanol abuse, tobacco use and infection by the bacteria Helicobacter pylori, which is the main etiological factor [1-3].

The infection by $H$. pylori, a gram-negative bacterium, is among the most frequent infections worldwide, affecting about $50 \%$ of the global population and about 4.4 billion individuals likely to be infected in 2015 worldwide [4,5]. Known as the most prevalent human pathogen, it reaches $80 \%$ of prevalence in developing countries and $25 \%$ in developed countries [6].

It is estimated that 10 to $20 \%$ of the infected patients develop gastric ulcerative disorders of several degrees and that 1 to $2 \%$ of them direct to develop gastric cancer [7-9]. The transmission of the bacteria occurs from person to person orally-oral and / or fecal-oral, and can be transmitted asymptomatically [10]. It is well known that there is a higher 
prevalence of this infection in childhood due to the constant contact between them. The specific reason for this prevalence is not yet elucidated [11,12].

The virulence factors of $H$. pylori includes a survival evolutionary mechanism, characterized by the production of urease enzyme which decomposes urea into ammonia and carbon dioxide, creating a less acidic microenvironment around the bacteria. In addition, the presence of polar flagella gives the microorganism the ability of locomotion. Both enhancements help the bacterium survival and colonization in the gastric environment [10,13-17]. The $H$. pylori mechanism activates the innate immune response inducing neutrophils infiltration, macrophages and $T$ and $B$ lymphocytes in the gastric mucosa due to expression of napA gene. The napA gene encodes the neutrophil activating protein (HP-NAP), which in turn increases the release of proinflammatory cytokines. Activated macrophages produce and release these pro-inflammatory cytokines (IL-1, IL-6, TNF- $\alpha$ ), reactive inorganic radicals and reactive oxygen species (ROS) and nitrogen (RNS) such as nitric oxide (NO), a radical that act as a cellular signal and is effective in the microbicidal and cytotoxic response of stimulated macrophages. Neutrophils, in turn, release large amounts of ROS. It is believed that the main cause of tissue damage is the combination of bacterial factors and the host's inflammatory mediators [18-21].

The treatment against $H$. pylori infection consists in the combination of amoxicillin, clarithromycin, and/or metronidazole, followed by a proton pump inhibitor. According to a study published in 2017 from the World Health Organization (WHO), among several antibiotic-resistant priority pathogens, $H$. pylori is classified as high priority to the development of new drugs [22,23]. The long-term therapy with multiple drugs, its high costs, the high incidence of side effects and the antimicrobial resistance, have led researchers to explore natural products as viable source for treatment of disorders related to $H$. pylori $[9,10,24]$. In this context, ethnopharmacological studies have contributed for new treatment alternatives, such as the use of the specie Maytenus ilicifolia, a high source for tannins and flavonoids, which was evidenced of its antiulcer activity and anti-inflammatory through in vivo and in vitro tests, being thus available as a herbal medicine [25].

Fruits, bark and mainly the leaves ofthe species Eugenia uniflora L. (Myrtaceae) commonly known as pitangueira, are used in traditional medicine for diverse purposes such as treating rheumatism, hypertension, bronchitis, cough, fever, anxiety, worms and dyspepsia [26]. Previous studies have reported antioxidant and antimicrobial potential [27]. The phytochemical analysis of the leaves indicated the presence of polyphenols such as tannins and flavonoids; saponins and sesquiterpenes in the essential oils [13,28-30]. $E$. uniflora was included in the National List of interesting Medicinal Plants of the Brazilian Universal Health System (SUS-RENISUS) which includes vegetal species with high potential to improve the available therapies and to develop herbal medicines to be used on the Unified Health System (SUS) [31]. In addition, this species is also included in the Brazilian Pharmacopoeia [32].

Thus, the aim of this study was to evaluate the potential of $E$. uniflora against $H$. pylori and its influence in the inflammatory overall process associated with the promoted infection, evaluating the antioxidant and immunomodulatory effects of this vegetal specie besides its chemical profile in the search for new drugs against $H$. pylori and its damages in the host.

\section{MATERIAL AND METHODS}

\section{Plant Collection}

Eugenia uniflora leaves were collected at 2017'53 "S - 4018'59" O, in Vitoria, Espirito Santo, Brazil. The botanical material was identified by Prof. Dr. Luciana Dias Thomas and deposited in the Herbarium VIES/UFES under number 40586. 


\section{Prepare Of The Plant Extract}

The collected leaves were submitted to drying in an oven with air circulation at a temperature of $38-40^{\circ} \mathrm{C}$. The leaves were then pulverized and extracted by maceration for 10 days with methanol $10 \% \mathrm{w} / \mathrm{v}$. Then, after filtration, the solvent was evaporated in a rotary evaporator under reduced pressure at $50{ }^{\circ} \mathrm{C}$, the dried extract being then stored at $-20^{\circ} \mathrm{C}$. DMSO was used as the solvent in the preparation of the stock solution.

\section{Total Phenolic Content Determination}

To determine the total phenol content (TPC) $125 \mu \mathrm{L}$ of the $10 \%$ Folin-Ciocalteau reagent aqueous solution and $25 \mu \mathrm{L}$ of the stock solution $(1 \mathrm{mg} / \mathrm{mL}$ diluted $1: 3$ in distilled water) were added to a 96 -well microplate. After 5 minutes, $100 \mu \mathrm{L}$ of $4 \%$ aqueous sodium carbonate solution were added. The reading was performed at the wavelength of $750 \mathrm{~nm}$ in a microplate reader (BioRad, Washington, USA), after approximately 2 hours incubation in the dark. The blank solution was all reagents except methanolic extract. Gallic acid was used as the standard for the calibration curve and for the expression of the result, which was given in milligrams of gallic acid per gram of sample (mg GAE/g) [33,34].

\section{Determination Of Tannin Content}

The stock solution of the initial sample was diluted $1: 3$ and $100 \mathrm{mg}$ casein was added to this solution. Then the solution was stirred for about 1 hour and then filtered. The blank solution was all reagents except methanolic extract. The total non-adsorbed phenols content (NAPC) by the casein is in the filtrate and was determined by the same method used to quantify the TPC. The tannin content was calculated by the difference between TPC and NAPC. Gallic acid was used as the standard for the calibration curve and for expression of the result given in milligrams of gallic acid per gram of sample (mg GAE/g) [35].

\section{Determination Of Flavonoid Content}

In a 96-well microplate, were added $99 \mu \mathrm{L}$ distilled water, $20 \mu \mathrm{L}$ sample (final concentration $100 \mu \mathrm{g} / \mathrm{mL}$ ), $6 \mu \mathrm{L}$ glacial acetic acid, $100 \mu \mathrm{L} 20 \%$ pyridine and $25 \mu \mathrm{L}$ aluminum chloride $6.5 \%$ in methanolic solution. After 30 minutes, spectrophotometric reading was performed on a microplate reader (BioRad, Washington, USA) at $415 \mathrm{~nm}$. Solution with all reagents, except the sample and aluminum chloride, was used as the blank of the reaction. The blank solution consisted of a solution containing all reagents except aluminum chloride. The flavonoid content was expressed as mg quercetin equivalents (QE) per gram of extract (mg QE/g) [36].

\section{Characterization of plant extract by Fourier Transform Ion Cyclotron Resonance Electrospray Ionization Mass Spectrometry (FT-ICR-ESI-MS)}

The E. uniflora $\mathrm{MeOH}$ extract was analyzed in a mass spectrometer (Model 9.4 T Solarix, Bruker Daltonics, Bremen, Germany), which was set to operate in negative ion mode, ESI(-), over a mass range of $m / z 200-1300$. The parameters of the ESI(-) source were as follows: nebulizer gas pressure of $0.5-1.0$ bar, capillary voltage of 3-3.5 kV, and transfer capillary temperature of $250^{\circ} \mathrm{C}$. The mass spectrum was processed using the Compass Data Analysis software package (Bruker Daltonics, Bremen, Germany). A resolving power, $\mathrm{m} / \square \mathrm{m}_{50 \%} \approx 500,000$, in which $\square \mathrm{m}_{50 \%}$ is the full peak width at half-maximum peak height of $\mathrm{m} / \mathrm{z} \approx 400$ and a mass accuracy of $<1 \mathrm{ppm}$, provided the unambiguous molecular formula assignments for singly charged molecular ions. Elemental compositions of the compounds were determined by measuring the $\mathrm{m} / \mathrm{z}$ values. The unsaturation level of each molecule could be deduced directly from its double bond equivalent (DBE), following 
the equation $D B E=c-h / 2+n / 2+1$, where $c, h$, and $n$ are the numbers of carbon, hydrogen, and nitrogen atoms, respectively. Molecular formula, measured $m / z$ values, DBE, and mass error are shown in Table 1.

\section{Bacterial Strain}

H. pylori INCQS 00390 (ATCC 43629) was obtained from Oswaldo Cruz Foundation (Fiocruz, RJ, Brazil).The bacteria was cultured on Columbia Agar supplemented with 5\% sheep blood and subsequently inoculated in BHI (Brain Heart Infusion) (Merck Millipore, Germany) supplemented with 10\% (v/v) fetal bovine serum (Sigma, USA), incubated for 72 hours at $37^{\circ} \mathrm{C}$ in an atmosphere containing $10 \% \mathrm{CO}_{2}$.

\section{Minimum Inhibitory Concentration (MIC) and Minimum Bactericidal Concentration (MBC) Determinations}

MIC and MBC determinations were performed both according to guidelines of the Clinical and Laboratory Standards Institute [37] (CLSI, norm M7-A10, 2015). For MIC determination, each well of the 96 well microplate was added $100 \mu \mathrm{L}$ of a suspension of $H$. pylori (ATCC 43629) (McFarland 0.5 solution $1: 20$ ), about $10^{6} \mathrm{cfu} / \mathrm{mL}$ in liquid culture medium $\mathrm{BHI}$ supplemented and $100 \mu \mathrm{L}$ of sample having final concentrations ranging from 32 to $1024 \mu \mathrm{g} / \mathrm{mL}$ in the same culture medium. The microplate was subjected to spectrophotometric reading at $620 \mathrm{~nm}$, and then incubated $\left(37^{\circ} \mathrm{C} / 10 \% \mathrm{CO}_{2} / 72\right.$ hours). After the incubation period, the microplate was homogenized and a new reading was performed to determine MIC.

The MIC was defined as the lowest concentration of the extract that induced an abrupt decline in the absorbance value (90\%). Amoxicillin (Sigma, USA) and metronidazole (Sigma, USA) were used as standards antibiotic control.

The MBC was determined by the lowest concentration of extract that inhibited the formation of colonies on Columbia Agar plates containing 5\% sheep blood (incubated at $37^{\circ} \mathrm{C} / 10 \% \mathrm{CO}_{2} / 72 \mathrm{~h}$ ) corresponding to the microplate well with no apparent growth of $\mathrm{BHI}$.

\section{Inhibition of Urease Enzyme}

In 96 microplate well were added $25 \mu \mathrm{L}$ of the protein urease (4UI) (Jack Bean Urease, Sigma, USA) and $25 \mu \mathrm{L}$ of the sample at concentrations ranging from 32 to $1024 \mu \mathrm{g} / \mathrm{mL}$, and incubated for 2 hours at room temperature. After that, $25 \mu \mathrm{L} 0.02 \%$ phenol red and $200 \mu \mathrm{L}$ $50 \mathrm{mM}$ urea were added in $100 \mathrm{mM}$ PBS buffer solution (pH 6.8). The absorbance of the reaction mixture was measured at $540 \mathrm{~nm}$ in a microplate reader (BioRad, Washington, USA) at time 0 and then every 10 minutes to evaluate the reaction kinetics [38]. Boric acid $\left(\mathrm{H}_{3} \mathrm{BO}_{3}\right)$ was used as a standard urease inhibitor.

\section{Antioxidant Activity Evaluation}

\section{The Superoxide Anion $\left(\mathrm{O}_{2}^{-}\right)$Scavenging Activity}

In a 96-well microplate, $225 \mu \mathrm{L}$ of phosphate buffer (PBS) $(50 \mathrm{mM}, \mathrm{pH} 7.4), 30 \mu \mathrm{L}$ of extract (3.125 to $100 \mu \mathrm{g} / \mathrm{mL}), 7.5 \mu \mathrm{L}$ of phenazine methosulfate (PMS) $(0.5 \mathrm{mM})$ and $30 \mu \mathrm{L}$ nitroblue tetrazolium (NBT) $(0.045 \mathrm{mM})$ were added. After two minutes, $7.5 \mu \mathrm{L}$ of NADH $(0.125 \mathrm{mM})$ were added. Finally, the spectrophotometric reading at $540 \mathrm{~nm}$ was performed after 10 minutes of incubation at room temperature protected from light [39]. Gallic acid was used as the antioxidant standard of this assay. 
Hypochlorous acid (HOCl) scavenging assay

The reaction with $\mathrm{HOCl}$ was studied based on the oxidation of 5-thio-2-nitrobenzoic acid (TNB) [40]. TNB was obtained by reducing a $1 \mathrm{mM}$ solution of 5,5-dithiobis(2-nitrobenzoic acid) (DTNB) in a $50 \mathrm{mM} \mathrm{KH}_{2} \mathrm{PO}_{4}-\mathrm{KOH}$ buffer (pH 6.6) containing $5 \mathrm{mM}$ EDTA and $20 \mathrm{mM}$ sodium borohydride and then quantified by molar extinction to obtain the final concentration $(140 \mu \mathrm{M})$. Then, in a 96-well microplate, $20 \mu \mathrm{L}$ of $\mathrm{HOCl}(25 \mu \mathrm{M}), 60 \mu \mathrm{L}$ of $50 \mathrm{mM}$ phosphate buffer ( $\mathrm{pH} \mathrm{6.6)}$ and $20 \mu \mathrm{L}$ of sample were added. After 2 minutes, $100 \mu \mathrm{L}$ of TNB solution (final concentration of $70 \mu \mathrm{M}$ ) were added, and the spectrophotometric reading was performed at $415 \mathrm{~nm}$ after 1 minute. Gallic acid was used as the antioxidant standard of this assay.

\section{Nitric Oxide (NO) scavenging assay}

The NO production was provided by sodium nitroprusside (SNP) molecules in PBS buffer. The assay was performed according to method provided by Marcocci et al. (1994), with modifications. Thus, SNP $(1.25 \mathrm{mM})$ was prepared in phosphate buffer $(0.1 \mathrm{M} \mathrm{pH} 7.0)$ in absence of light. In a 96 -well plate, $50 \mu \mathrm{L}$ of SNP and $50 \mu \mathrm{L}$ of samples at various concentrations (ranging from 25 to $800 \mu \mathrm{g} / \mathrm{mL}$ ) were added and incubated for $1 \mathrm{~h}$ at room temperature with exposure to light. After incubation, $100 \mu \mathrm{L}$ of Griess reagent $(1 \% \mathrm{w} / \mathrm{v}$ sulfanilamide, $0.1 \% \mathrm{w} / \mathrm{v}$ of naphthylethylenediamine and $2.5 \% \mathrm{v} / \mathrm{v}$ of orthophosphoric acid) were added and the reaction mixture was read at $540 \mathrm{~nm}$. A calibration curve with sodium nitrite $\left(\mathrm{NaNO}_{2}\right)$ was generated to represent the data from $\mathrm{NO}_{2}{ }^{-}$formation. Gallic acid was used as the antioxidant standard of this assay.

\section{Immunomodulatory Activity}

\section{Cell Culture}

Nitric oxide (NO) and cytokine (TNF- $\alpha$ and IL-6) detection assays were performed using the murine macrophages RAW 264.7 (ATCC TIB-71). Cells were maintained in bottles with Dulbecco's Modified Eagle Medium supplemented with $10 \%(\mathrm{v} / \mathrm{v})$ fetal bovine serum and incubated for different periods at $37^{\circ} \mathrm{C}$ in a $5 \% \mathrm{CO}_{2}$ atmosphere until reaching a confluence of approximately $70-90 \%$. After obtaining the desired confluence, the cells were dissociated using a cell scraper and counted in a Neubauer chamber to obtain cell concentration values.

\section{Cell viability by MTT assay}

Cytotoxicity assay was performed to determine the non-cytotoxic concentrations of extracts for macrophages. Aliquots $(0.2 \mathrm{~mL})$ of medium containing macrophages were seeded into 96 -well tissue-culture plates at $2 \times 10^{5}$ cells $/ \mathrm{mL}$. After $2 \mathrm{~h}$, the medium was removed and the adherent cells were incubated with the extracts for $24 \mathrm{~h}$. After incubation, the medium was removed, and the macrophages were incubated with MTT solution (1 $\mathrm{mg} / \mathrm{mL}$ ) for $3 \mathrm{~h}$ [42]. The formazan formed was dissolved in DMSO, and the optical density was measured using a microplate reader with a $540 \mathrm{~nm}$ filter and $620 \mathrm{~nm}$ reference filter. The optical density of the dissolved formazan in the control (untreated cells) was taken to be $100 \%$ viable.

\section{Measurement of cytokine production (TNF- $\alpha$ and IL-6) and NO}

The cells were distributed into 24 well plates at a concentration of $5 \times 10^{6}$ of viable cells per $\mathrm{mL}$ to the IL- 6 and NO assays and $2 \times 10^{5}$ viable cells $/ \mathrm{mL}$ for the TNF- $\alpha$ assay DMEM solution. After two hours of incubation $\left(37^{\circ} \mathrm{C} / 5 \%\right.$ of $\left.\mathrm{CO}_{2}\right)$ for cell adhesion, the supernatant was discarded and the cells were stimulated with Escherichia coli lipopolysaccharides (LPS) 
(Sigma, USA) at a concentration of $1 \mu \mathrm{g} / \mathrm{mL}$, receiving at the same time, different concentrations of the extract (previously determined by cytotoxicity assays). The plates were incubated overnight $\left(37^{\circ} \mathrm{C} / 5 \%\right.$ of $\left.\mathrm{CO}_{2}\right)$. After that, the supernatants were collected in order to detect and quantify the present cytokines (TNF- $\alpha$ and IL-6) by enzyme immunoassay (eBioscience, USA) and NO by the Griess method [43]. Additionally, cytotoxicity was evaluated after all assays by MTT method.

\section{Statistical Analysis}

Statistical differences were determined by analysis of variance (ANOVA) of two-way with Tukey post-test and $p \leq 0.05$ as statistically significant. Linear regression tests were also conducted for the $\mathrm{EC}_{50}$ values.

\section{RESULTS}

\section{Phytochemical Analysis}

\section{Total Phenols, Tannins and Flavonoids Contents}

The values obtained in the total phenol and tannins quantification are 193.06 (19.31\%) and $161.29(16.13 \%)$, respectively, presented in milligram equivalent of gallic acid (mgEAG/g) and the values obtained in the flavonoids quantification are $28.64(2.86 \%)$ presented in milligram equivalent of quercetin $(\mathrm{mgEQ} / \mathrm{g})$ per gram of extract.

Characterization of plant extract by Fourier Transform Ion Cyclotron Resonance Electrospray Ionization Mass Spectrometry (FT-ICR-ESI-MS)

The (-) - ESI FT-ICR MS technique was applied to analysis of E. uniflora MeOH extract. The exact molecular mass of the compounds present in the extract makes it possible to obtain a reliable chemical profile of the analyzed solutions (Table 1). Because of the ionization method used was electrospray in negative mode, acidic molecules like phenolic acids, flavonoids, acid triterpenes, tannins and alcohols such as carbohydrates were properly ionized to be analyzed. Important Myrtaceae chemical classes present in the extract, were: gallotannins [44], ellagitannins [44], flavonoids [45], phenylpropanoids like caffeoylquinic acid, triterpenoids [46] and sesquiterpenoids [47]. Quinic acid was ionized as its chloride cluster at [M-H]- 227. Myricitrin and myricetin, important flavonoids of E. uniflora were identified at 463, 499 (chloride cluster) and 317 respectively [48]. For further information, access the supplementary material, Figure $\mathrm{S} 1$. 
Table 1. Molecular formula, $\mathrm{DBE}$, and mass error of the $E$. uniflora $\mathrm{MeOH}$ extract by electrospray ionization mass spectrometry

\begin{tabular}{llllll}
\hline [M-H] & $\begin{array}{c}\text { Molecular } \\
\text { Formula } \\
(\mathbf{m} / \mathbf{z})\end{array}$ & $\begin{array}{c}\text { Error } \\
(\mathbf{p p m})\end{array}$ & DBE & $\begin{array}{c}\text { Signal } \\
\text { Intensity (\%) }\end{array}$ & $\begin{array}{c}\text { Proposed Substance or Class } \\
\text { of Substance }\end{array}$ \\
\hline 215.03306 & $\mathrm{C}_{6} \mathrm{H}_{12} \mathrm{ClO}_{6}$ & -1.26 & 0.5 & 6.43 & Monosaccharide chloride cluster \\
227.03309 & $\mathrm{C}_{7} \mathrm{H}_{12} \mathrm{ClO}_{6}$ & -1.32 & 1.5 & 1.59 & Quinic acid chloride cluster \\
283.11105 & $\mathrm{C}_{15} \mathrm{H}_{20} \mathrm{ClO}_{3}$ & -1.43 & 5.5 & 1.44 & Sesquiterpene chloride cluster \\
299.10602 & $\mathrm{C}_{15} \mathrm{H}_{20} \mathrm{ClO}_{4}$ & -1.43 & 5.5 & 2.86 & Sesquiterpene chloride cluster \\
300.99949 & $\mathrm{C}_{14} \mathrm{H}_{5} \mathrm{O}_{8}$ & -1.67 & 12.5 & 4.81 & Ellagic acid \\
317.0307 & $\mathrm{C}_{15} \mathrm{H}_{9} \mathrm{O}_{8}$ & -1.29 & 11.5 & 0.96 & Myricetin \\
341.10935 & $\mathrm{C}_{12} \mathrm{H}_{21} \mathrm{O}_{11}$ & -1.22 & 2.5 & 0.94 & Disaccharide \\
343.06765 & $\mathrm{C}_{14} \mathrm{H}_{15} \mathrm{O}_{10}$ & -1.70 & 7.5 & 1.38 & Galloyl quinic acid \\
353.08846 & $\mathrm{C}_{16} \mathrm{H}_{17} \mathrm{O}_{9}$ & -1.85 & 8.5 & 1.78 & Caffeoyl quinic acid \\
361.07817 & $\mathrm{C}_{14} \mathrm{H}_{17} \mathrm{O}_{11}$ & -1.47 & 6.5 & 37.72 & Galloylheptose \\
371.12006 & $\mathrm{C}_{13} \mathrm{H}_{23} \mathrm{O}_{12}$ & -1.50 & 2.5 & 34.64 & Disaccharide \\
377.0862 & $\mathrm{C}_{12} \mathrm{H}_{22} \mathrm{ClO}_{11}$ & -1.55 & 1.5 & 14.45 & Disaccharide chloride cluster \\
383.12004 & $\mathrm{C}_{14} \mathrm{H}_{23} \mathrm{O}_{12}$ & -1.42 & 3.5 & 100.0 & Disaccharide \\
463.08694 & $\mathrm{C}_{21} \mathrm{H}_{19} \mathrm{O}_{12}$ & 2.73 & 12.5 & 0.88 & Myricitrin \\
467.08412 & $\mathrm{C}_{20} \mathrm{H}_{19} \mathrm{O}_{13}$ & -2.15 & 11.5 & 6.80 & Digalloylhexose \\
469.00589 & $\mathrm{C}_{21} \mathrm{H}_{9} \mathrm{O}_{13}$ & -2.19 & 17.5 & 3.55 & Ellagitannin \\
499.06593 & $\mathrm{C}_{21} \mathrm{H}_{20} \mathrm{ClO}_{12}$ & -2.10 & 11.5 & 16.0 & Myricitrin chloride cluster \\
523.32062 & $\mathrm{C}_{30} \mathrm{H}_{48} \mathrm{ClO}_{5}$ & -1.99 & 6.5 & 21.06 & Triterpene acid chloride cluster \\
533.1734 & $\mathrm{C}_{19} \mathrm{H}_{33} \mathrm{O}_{17}$ & -2.02 & 3.5 & 21.36 & Trisaccharide \\
655.15336 & $\mathrm{C}_{28} \mathrm{H}_{31} \mathrm{O}_{18}$ & -2.71 & 13.5 & 9.85 & Flavonoid glycoside \\
679.40824 & $\mathrm{C}_{37} \mathrm{H}_{59} \mathrm{O}_{11}$ & -2.88 & 8.5 & 5.14 & Triterpene glycoside \\
\hline
\end{tabular}

\section{Determination of Minimum Inhibitory Concentration (MIC) and Minimum Bactericidal Concentration (MBC)}

The MIC value of the $\mathrm{MeOH}$ extract fraction of $E$. uniflora against $H$. pylori was 128 $\mu \mathrm{g} / \mathrm{mL}$.Despite all concentrations tested, no MBC values were detected since colony formation were identified in the Columbia Agar lamb blood solution (5\%). The reference compounds, metronidazole and amoxicillin, presented $\mathrm{MIC}>512 \mu \mathrm{g} / \mathrm{mL}$ and $\mathrm{MIC} 0.125$ $\mu \mathrm{g} / \mathrm{mL}$, respectively.

\section{Inhibition Of Urease Enzyme}

Figure 1 shows the results for urease inhibition profile, evidencing an inhibition constant value of $E$. uniflora $\mathrm{MeOH}$ extract at all tested concentrations (32 to $1024 \mu \mathrm{g} / \mathrm{mL}$ ) ranging from 20.501 to $24.363 \%$, which is $(32-512 \mu \mathrm{g} / \mathrm{mL})$ showed no statistical difference in relation to boric acid (inhibition control). 


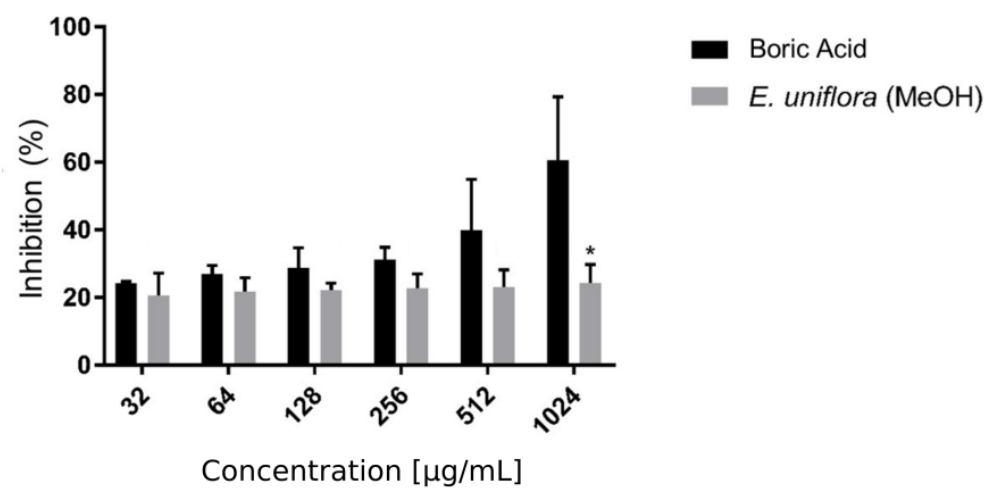

Figure 1. Urease inhibition assay. Results of the urease enzyme inhibition assay (\% inhibition vs. sample concentration). Results presented as mean \pm standard deviation of at least three independent experiments. ${ }^{*} \mathrm{p}<0.05$ compared to boric acid.

\section{Antioxidant Activity Evaluation}

The $\mathrm{EC}_{50}$ of $\mathrm{O}_{2}{ }^{*}, \mathrm{HOCl}$ and $\mathrm{NO}^{*}$ for the $E$. uniflora $\mathrm{MeOH}$ extract were 29.77, 15.71 and $442.10 \mu \mathrm{g} / \mathrm{mL}$, respectively, while the gallic acid, showed values of $30.84,<3.125$ and $228.40 \mu \mathrm{g} / \mathrm{mL}$, respectively, evidencing the ability of the extract to block the action of reactive oxygen species as $\mathrm{O}_{2}{ }^{*}$ and $\mathrm{HOCl}$.

\section{Immunomodulatory Activity Evaluation}

The extract concentrations used for the macrophage assays were defined according to the previously cytotoxicity assay performed, selecting those with no influence on cell viability. The effect of $E$. uniflora MeOH extract of LPS-stimulated macrophages are shown in Figure 2 which presents the quantification of TNF- $\alpha$, IL- 6 and NOThe inhibition of IL- 6 and NO (80 and $100 \%$, respectively) at concentration of $100 \mu \mathrm{g} / \mathrm{mL}$, was observed in a dose-dependent mannerInhibition for TNF- $\alpha$ at the same concentration was $40 \%$.
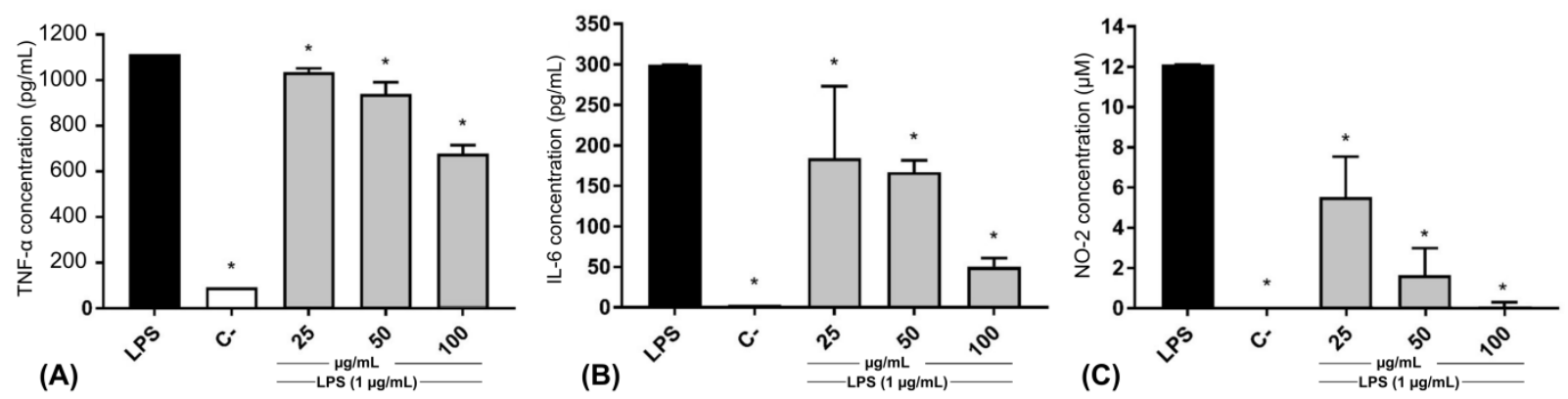

Figure 2. Effects of $E$. uniflora $\mathrm{MeOH}$ extract $(\mu \mathrm{g} / \mathrm{mL})$ on LPS-stimulated macrophages on: TNF- $\alpha$ release $(A)$; IL-6 release $(B)$; NO release $(C)$. Cells incubated just with LPS were used as a positive control and cells in culture medium (DMEM) as a negative control (C-). ${ }^{*} p<0.05$ vs. LPS control. Results presented as mean $\pm S D$ of at least three independent experiments.

\section{DISCUSSION}

H. pylori have been associated with the pathogenesis of gastritis, peptic ulcer and gastric cancer. The microorganism has been classified as a Group I carcinogen by the International Agency for Research on Cancer (IARC) since 1994, and in 2014 it accounts for $78 \%$ of the world's cases of gastric cancer. The infection of the gastric mucosa by $\mathrm{H}$. pylori is associated with excessive inflammatory response and tissue damage, since the 
microorganism stimulates the respiratory burst in neutrophils increasing ROS production, furthermore modulates NADPH oxidase so that the radicals are released in the extracellular environment and not within the phagosomes where the bacterium is found [18,21].

The high prevalence of $H$. pylori strains resistant to clarithromycin and metronidazole and especially the difficulty of antimicrobial action in the stomach environment due to the acid $\mathrm{pH}$ associated with the difficulties to access to the microorganism region have led to a need for alternative solutions to diminish or control of the infection [49].

Previous reports with plants of the same family (Myrtaceae), indicates that the extract evaluated in this study presented better anti-H. pylori activity than species such Myrciaria cauliflora (MIC $256 \mu \mathrm{g} / \mathrm{mL}$ ), Myrtus communnis (MIC $500 \mu \mathrm{g} / \mathrm{mL}$ ) and Syzygium aromaticum (MIC $500 \mu \mathrm{g} / \mathrm{mL}$ ) [50]. Additionally, E. uniflora did not show MBC at $1024 \mu \mathrm{g} / \mathrm{mL}$. The absence of MBC suggests bacteriostatic activity. The bacteria proliferation inhibition is of great importance since the $H$. pylori has several defense mechanisms against the host cells and thus an attenuated bacteria or a metabolically weakened one, it is more susceptible to the immune system [51].

The E. uniflora MeOH extract demonstrated ability to inhibit the enzyme urease, as in previous studies with other species of the same family as Myrciaria caulifora, Eucalyptus grandis and Myrtus communis [52]. These results were in accordance with the (-) - ESI FT-ICR MS technique applied to analysis of the methanolic extract of $E$. uniflora leaves indicating the major presence of tannins and flavonoids, which have the capacity of produce complexes and consequent inhibition of bacterial enzymes [53]. In this study, inhibition of urease may be related mainly to tannins $(16.13 \%)$ due to their higher content compared to flavonoids (2.86\%). Many compounds from plants have biological activity, specially anti-ulceration and antimicrobial character, such as flavonoids, tannins and terpenoids, and therefore powerful allies in the eradication of $H$. pylori. The phytochemical screening and the FT-ICR-ESI-MS identification of major components of $E$. uniflora $\mathrm{MeOH}$ extract evidenced the presence of tannins and flavonoids, in accordance with previously reports of the Brazilian Pharmacopeia V (2010) and several scientific studies [28,30,32].

$(-)$ - ESI FT-ICR MS technique was applied to analysis E. uniflora MeOH extract and the choice for the negative ionization method for the methanolic extract was based on the fact that E. uniflora leaves are a rich source of phenolic compounds [54]. Although carbohydrates are less acid than phenolic compounds, they showed intense peaks on the mass spectrum (Figure S1), indicating that carbohydrates should be the major compounds of the extract.

The evidence of the ability of $H$. pylori to induce the production of reactive species by neutrophils and macrophages causing oxidative stress, led us to evaluate the capacity of the extract to capture oxidants such as $\mathrm{O}_{2}{ }^{-}, \mathrm{HOCl}$ and $\mathrm{NO}$ [18].

The results indicates the capacity of $E$. uniflora $\mathrm{MeOH}$ extract to capture the oxidants $\mathrm{O}_{2}{ }^{*-}$ and $\mathrm{HOCl}$ compared to gallic acid, notably for $\mathrm{HOCl}$ scavenging capacity $(84.98 \%$, $85.69 \%$ at 50 and $100 \mu \mathrm{g} / \mathrm{mL}$, respectively). This effect may be related to the presence of total phenol, tannins and flavonoids by phenol stabilization from quinone production [55]. When compared to literature data, E. uniflora presents better capability to capture $\mathrm{O}_{2}{ }^{*-}$ than plants of the same family such as Eugenia stipitata $\left(E_{50} 126.14 \mu \mathrm{g} / \mathrm{mL}\right)$ and Syzygium malaccense $\left(\mathrm{EC}_{50} 30.49 \mu \mathrm{g} / \mathrm{mL}\right.$ ) [56]. However, the extract did not show significant data on NO scavenging.

Macrophages were stimulated with LPS for cellular activation and release of inflammatory mediators, including increased inducible nitric oxide synthase (iNOS) with the generation of $\mathrm{NO}$ and proinflammatory cytokines. In this study, the results showed the $E$. uniflora $\mathrm{MeOH}$ extract ability to inhibit the formation and/or to capture NO produced by LPS-stimulated macrophages. This inhibition can be due to the direct capture, inhibition of iNOS and/or modulation of transcription factors in the cascade of NO formation. In assessing the ability of NO scavenging by the chemical method, E. uniflora $\mathrm{MeOH}$ extract demonstrated inhibition about $20 \%$ at $100 \mu \mathrm{g} / \mathrm{mL}$, indicating the possibility of the extract to 
inhibit iNOS in a greater extent, since 100\% inhibition was demonstrated in the LPS-stimulated macrophage assay at the same concentration.

Due to the mutagenic effect of $\mathrm{NO}$, its excessive production during the immune response to $H$. pylori, could be related to the development of gastric cancer $[1,57]$. Furthermore, the $\mathrm{ONOO}^{-}$ions generated from NO, is far more cytotoxic than NO due to its instability and short half-life, causing DNA damage, closely related to carcinogenesis [58]. Thus, the ability to inhibit $\mathrm{NO}$ is an important resource in the gastric cancer prevention associated with $H$. pylori.

The immunomodulatory results from the $E$. uniflora $\mathrm{MeOH}$ extract presented $\mathrm{NO}$, TNF- $\alpha$ and IL-6 inhibition profile. The extract at $100 \mu \mathrm{g} / \mathrm{mL}$ demonstrated the ability to inhibit IL-6 $(83.19 \%)$, TNF- $\alpha(39.10 \%)$, and NO $(97.12 \%)$.

The $\mathrm{NO}$ and cytokines inhibition by $E$. uniflora $\mathrm{MeOH}$ extract could be related to an anti-ulcer mechanism, since TNF- $\alpha$ and IL- 6 are programmed to recruit more inflammatory cells to consequently produce reactive species such as $\mathrm{NO}$, responsible for damage to the gastric tissue.

Although the inhibition mechanism of these cytokines has not been clearly elucidated, an independent anti-inflammatory pathway not related to the common cyclooxygenase-1 (COX-1) enzyme inhibition is an interesting approach. The usual COX-1 inhibition of this enzyme leads to severe gastric damage due to the hindrance of prostaglandins production and hence their homeostatic protective function of gastric epithelium and increased mucus production, contributing to the epithelium regeneration [59].

In this context, inhibition of pro-inflammatory cytokines would act on cell infiltration and release of reactive species during the inflammatory process, reducing the chances of tissue damage and cancer development. Chronic inflammation regulation is an important role in the etiology of cancer, the anti-H. pylori and anti-inflammatory profile of $E$. uniflora $\mathrm{MeOH}$ extract could help in treating lesions caused by this bacterium to prevent the establishment of gastric cancer.

\section{CONCLUSION}

The $\mathrm{MeOH}$ extract of $E$. uniflora presented $H$. pylori bacteriostatic activity. However, other activities related to the infection were found, such as the antioxidant activity by the capture of the oxidants $\mathrm{O}_{2}{ }^{-*}$ and $\mathrm{HOCl}$ and the immunomodulatory activity expressed by $\mathrm{NO}$, TNF- $\alpha$ and IL- 6 inhibition. All this reported activities from $E$. uniflora $\mathrm{MeOH}$ extract could be related to the FT-ICR-ESI-MS identification of major components as flavonoids and tannins highlighting this vegetal specie as a valuable source in the search of new treatments for $H$. pylori infection.

Funding: This study was financed by FAPES/CNPq, process number 71932879/2015.

Acknowledgments The authors thank CAPES and FAPES for the scholarship granted to J.R.M.B., J.S.A., B.R.A. and R.P.R.

Conflicts of Interest

The authors declare no conflict of interest.

\section{REFERENCES}

1. Brown LF, Wilson DE. Gastroduodenal ulcers: causes, diagnosis, prevention and treatment. Compr Ther. 1999;25:30-8.

2. Dimaline R, Varro A. Attack and defence in the gastric epithelium - a delicate balance. Exp Physiol. 2007;92:591-601.

3. Ddine LC, Ddine CC, Rodrigues CCR, Kirsten VR, Colpo E. Fatores associados com a gastrite crônica em pacientes com presença ou ausência do Helicobacter pylori. ABCD Arq Bras Cir Dig. 2012;25:96-100. 
4. Hooi JKY, Lai WY, Ng WK, Suen MMY, Underwood FE, Tanyingoh D. Global Prevalence of Helicobacter pylori Infection: Systematic Review and Meta-Analysis.

Gastroenterol.2017;153:420-9.

5. Toscano EP, Madeira FF, Dutra-Rulli MP, Gonçalves LOM, Proença MA, Borghi VS. Epidemiological and Clinical-Pathological Aspects of Helicobacter pylori Infection in Brazilian Children and Adults. Gastroenterol Res Pract. 2018:1-8.

6. Khademi F, Sahebkar AH, Vaez H, Arzanlou M, Peeridogaheh H. Characterization of clarithromycin-resistant Helicobacter pylori strains in Iran: A systematic review and meta-analysis. J Glob Antimicrob Resist. 2017;10:171-8.

7. McColl KEL. Helicobacter pylori Infection. N Engl J Med. 2010;362:1597-604.

8. Romero-Adriàn TB, Leal-Montiel J. Helicobacter pylori Infection: Regulatory T Cells and Their Participation in the Immune Response. Jundishapur J Microbiol. 2013;6(4):5183.

9. Kusters JG, van Vliet AHM, Kuipers EJ. Pathogenesis of Helicobacter pylori Infection. Clin Microbiol Rev. 2006;19:449-90.

10. Amieva MR, El-Omar EM. Host-Bacterial Interactions in Helicobacter pylori Infection. Gastroenterol. 2008;134:306-23.

11. Mourad-Baars P, Hussey S, Jones NL. Helicobacter pylori Infection and Childhood. Helicobacter. 2010;15:53-9.

12. Daugule I, Rowland M. Helicobacter pylori infection in children. Helicobacter. 2008;13:41-6.

13. Ladeira MSP, Salvadori DMF, Rodrigues MAM. Biopatologia do Helicobacter pylori. J Bras Patol e Med Lab. 2003;39:335-42.

14. Phadnis SH, Parlow MH, Levy M, Ilver D, Caulkins C.M, Connors J.B. Surface localization of Helicobacter pylori urease and a heat shock protein homolog requires bacterial autolysis. Infect Immun. 1996;64:905-12.

15. Weeks DL, Sachs $\mathrm{G}$. Sites of $\mathrm{pH}$ regulation of the urea channel of Helicobacter pylori. Mol Microbiol. 2001;40:1249-59.

16. Bauer B, Meyer TF. The Human Gastric Pathogen Helicobacter pylori and Its Association with Gastric Cancer and Ulcer Disease. Ulcers. 2011;1-23.

17. Ramis IB, Vianna JS, Gonçalves CV, von Groll A, Dellagostin OA, da Silva PEA.

Polymorphisms of the IL-6, IL-8 and IL-10 genes and the risk of gastric pathology in patients infected with Helicobacter pylori. J Microbiol Immunol Infect. 2017;50:153-9.

18. Allen LA, Beecher BR, Lynch JT, Rohner OV, Wittine LM. Helicobacter pylori disrupts NADPH oxidase targeting in human neutrophils to induce extracellular superoxide release. $J$ Immunol. 2005;174:3658-67.

19. Bonacorsi C, Raddi MSG, Carlos IZ, Sannomiya M, Vilegas W. Anti-Helicobacter pylori activity and immunostimulatory effect of extracts from Byrsonima crassa Nied.

(Malpighiaceae). BMC Complement Altern Med. 2009;9:1-7.

20. Bonacorsi C, Da Fonseca LM, Raddi MSG, Kitagawa RR, Vilegas W. Comparison of Brazilian plants used to treat gastritis on the oxidative burst of Helicobacter pylori -stimulated neutrophil. Evidence-based Complement Altern Med. 2013;2013.

21. Smoot DT, Elliot TB, Versapaget HW, Jones D, Allen CR, Vernon KG. Influence of Helicobacter pylori on reactive oxygen-induced gastric epithelial cell injury. Carcinogenesis. 2000;21:2091-5.

22. Shrivastava S, Shrivastava P, Ramasamy J. World health organization releases global priority list of antibiotic-resistant bacteria to guide research, discovery, and development of new antibiotics. J Med Soc. 2017;32:76.

23. WHO. Global Priority List Of Antibiotic-Resistant Bacteria To Guide Research, Discovery And Development Of New Antibiotics. World Heal. Organ. 2017.

24. Kitagawa RR, Bonacorsi C, da Fonseca LM, Vilegas W, Raddi MSG. Anti-Helicobacter pylori activity and oxidative burst inhibition by the naphthoquinone

5-methoxy-3,4-dehydroxanthomegnin from Paepalanthus latipes. Brazilian J Pharmacogn. 2011;22:53-9.

25. Barbosa WLR. Etnofarmácia - Fitoterapia Popular e Ciência Farmacêutica. Curitiba (PR): Ed. CRV; 2011. 132 p.

26. Queiroz JMG, Suzuki MCM, Motta APR, Nogueira JMR, Carvalho EM. Aspectos populares e científicos do uso de espécies de Eugenia como fitoterápico. Rev Fitos. 2015;9(2):87-100. 
27. Costa BL. Avaliação da composição química e das atividades antimicrobiana e antioxidante dos extratos de Eugenia uniflora [Trabalho de Conclusão de Curso]. Brasilia (DF): Universidade de Brasília; 2015. 45 p.

28. Mei-Hsien L, Nishimoto S, Ling-Ling Y, Kun-Ying Y, Hatano T, Yoshida T. Two macrocyclic hydrolysable tannin dimers from Eugenia uniflora. Phytochemistry. 1997;44:1343-9.

29. Lorenzi H, Matos FJA. Plantas Medicinais no Brasil - Nativas e Exóticas. São Paulo (SP): Nova Odessa: Instituto Plantarum; 2002. 512 p.

30. Fiuza TS, Rezende MH, Sabóia-Morais SMT, Bara MTF, Tresvenzol LMF, Paula JR. Caracterização farmacognóstica das folhas de Eugenia unifloral L. (Myrtaceae). Rev Eletrônica Farmácia. 2008;2:1-11.

31. Brasil. Ministério da Saúde. Direção de Administração e Finanças. Secretaria de Ciência, Tecnologia e Insumos Estratégicos. RENISUS - Relação Nacional de Plantas Medicinais de Interesse ao SUS. Agência Saúde 2009.

32. Farmacopéia ANDVS. Farmacopeia Brasileira. Farm Bras 5a edição. 2010;1:1-523.

33. Neves LC, Alencar SM, Carpes ST. Determinação da atividade antioxidante e do teor de compostos fenólicos e flavonoides totais em amostras de pólen apícola de Apis mellifera. Brazilian J Food Technol. 2009;7:107-10.

34. Singleton VL, Rossi JA. Colorimetry of Total Phenolics with

Phosphomolybidic-Phosphotungstic Acid Reagents. Am J Enol Vitic. 1965;16:144-9.

35. Dimech GS, Soares LAL. Ferreira MA, De Oliveira AGV, Carvalho MDC, Ximenes EA. Phytochemical and antibacterial investigations of the extracts and fractions from the stem bark of Hymenaea stigonocarpa Mart. ex Hayne and effect on ultrastructure of Staphylococcus aureus induced by hydroalcoholic extract. Sci World J. 2013;2013.

36. Marques GS, Monteiro RPM, De Figueirêdo LW, Lyra MAM, Peixoto MS, Rolim-Neto PJ. Avaliação de procedimentos para quantificação espectrofotométrica de flavonoides totais em folhas de Bauhinia forfcata link. Quim Nova. 2012;35:517-22.

37. Clinical and Laboratory Standards Institute. M07-A10. Methods for Dilution Antimicrobial Susceptibility Tests for Bacteria That Grow Aerobically. Approv. Stand. Ed. CLSI Doc. M07-A10. 2015.

38. Tanaka T, Kawase M, Tani S. Urease inhibitory activity of simple $\alpha, \beta$-unsaturated ketones. Life Sci. 2003;73:2985-90.

39. Suzumura K, Yasuhara M, Narita H. Superoxide anion scavengin properties of fluvastatin and its metabolites. Chem Pharm Bull. 1999;47:1477-80.

40. Ching TL, de Jong J, Bast A. A method for screening hypochlorous acid scavengers by inhibition of the oxidation of 5-thio-2-nitrobenzoic acid: application to anti-asthmatic drugs.

Anal. Biochem. 1994;218(2):377-81.

41. Marcocci L, Maguire JJ, Droylefaix MT, Packer L. The Nitric Oxide-Scavenging Properties of Ginkgo Biloba Extract EGb 761. Biochem Biophys Res Commun. 1994;201:748-55.

42. Mosmann T. Rapid colorimetric assay for cellular growth and survival: Application to proliferation and cytotoxicity assays. J Immunol Methods. 1983;65:55-63.

43. Corporation P, Miranda KM, Espey MG, Wink DA. Griess Reagent System. Nitric Oxide. 2009;5:7.

44. Fortes GAC, Carvalho AG, Ramalho RRF, da Silva AJR, Ferri PH, Santos SC. Antioxidant activities of hydrolysable tannins and flavonoid glycosides isolated from Eugenia uniflora L. Rec Nat Prod. 2015;9:251-6.

45. Oliveira AL, Destandau $E$, Fougère $L$, Lafosse $M$. Isolation by pressurised fluid extraction (PFE) and identification using CPC and HPLC/ESI/MS of phenolic compounds from Brazilian cherry seeds (Eugenia uniflora L.). Food Chem. 2014;145:522-9.

46. Hill RA, Connolly JD. Triterpenoids. Nat Prod Rep. 2013;30(7):1028-65.

47. Amorim ACL, Lima CF, Hovell AMC, Miranda ALP, Rezende CM. Antinociceptive and hypothermic evaluation of the leaf essential oil and isolated terpenoids from Eugenia uniflora L. (Brazilian Pitanga). Phytomedicine. 2009;16:923-8.

48. Rattmann YD, de Souza LM, Malquevicz-Paiva SM, Dartora N, Sassaki GL, Gorin PAJ. Analysis of Flavonoids from Eugenia uniflora Leaves and Its Protective Effect against Murine Sepsis. Evidence-Based Complement Altern Med. 2012;2012:1-9. 
49. Graham DY, Lee YC, Wu MS. Rational helicobacter pylori therapy: Evidence-based medicine rather than medicine-based evidence. Clin Gastroenterol Hepatol. 2014;12:17786.

50. Zaidi SFH, Yamada K, Kadowaki M, Usmanghani K, Sugiyama T. Bactericidal activity of medicinal plants, employed for the treatment of gastrointestinal ailments, against Helicobacter pylori. J Ethnopharmacol. 2009;121:286-91.

51. Pankey GA, Sabath LD. Clinical relevance of bacteriostatic versus bactericidal mechanisms of action in the treatment of Gram-positive bacterial infections. Clin Infect Dis an Off Publ Infect Dis Soc Am. 2004;38:864-70.

52. Nabati F, Mojab F, Habibi-Rezaei M, Bagherzadeh K, Amanlou M, Yousefi B. Large scale screening of commonly used Iranian traditional medicinal plants against urease activity. DARU J Pharm Sci. 2012;20(1):72-81.

53. Moilanen J, Salminen JP. Ecologically neglected tannins and their biologically relevant activity: chemical structures of plant ellagitannins reveal their in vitro oxidative activity at high pH. Chemoecol. 2008;18:73-83.

54. de Oliveira FMG, Romão W, Kuster RM. Identification of phenolic compounds in Eugenia uniflora leaves by FTICR MS in association with different ionization sources. Anal Methods. 2018;10:1647-55.

55. Procházková D, Boušová I, Wilhelmová N. Antioxidant and prooxidant properties of flavonoids. Fitoterapia. 2011;82:513-23.

56. Costa MP. Estudo da atividade antioxidante de frutas tropicais exóticas sobre espécies reativas de oxigênio de importância biológica em ensaios modelos [dissertação].

Araraquara: Universidade Estadual Paulista, Faculdade de Ciências Farmacêuticas; 2010. Xxp.

57. Wilson K, Ramanujam K, Mobley H, Musselman R, James S, Meltzer S. Helicobacter pylori stimulates inducible nitric oxide synthase expression and activity in a murine macrophage cell line. Gastroenterol. 1996;111:1524-33.

58. Lala PK, Chakraborty C. Role of nitric oxide in carcinogenesis and tumour progression. Lancet Oncol. 2001;2:149-56.

59. Fornai M, Antonioli L, Colucci R, Tuccori M, Blandizzi C. Pathophysiology of Gastric Ulcer Development and Healing: Molecular Mechanisms and Novel Therapeutic Options. In: Peptic Ulcer Dis. London: InTech; 2011. p.113-142.

(C) 2018 by the authors. Submitted for possible open access publication under the terms and conditions of the Creative Commons Attribution (CC BY NC) license (https://creativecommons.org/licenses/by-nc/4.0/). 